I996

Spring

I996

Printemps
Papers of the

Bibliographical Society

of Canada

Cahiers de la

Société bibliographique

du Canada

Volume 34, \# I

The Bibliographical Society of Canada

La Société bibliographique du Canada Toronto, Canada I996

ISSN 0067-6896 
(@)

Printed on acid-free paper. Imprimé sur papier sans acide. 


\section{Table of Contents / Table des matières}

Editorial Note / Préliminaire

The Bibliographical Society of Canada Celebrates Its Fiftieth Anniversary: Looking Back and Looking Forward / La Société bibliographique du Canada célèbre son cinquantième anniversaire: Vers le passé et vers l'avenir CARL SPADONI

The Publication of Songs of a Sourdough

PETER J. MITHAM

Books in Review / Comptes rendus

MICHEL BRISEBOIS and / et FRANÇOIS MELANÇON

Michel Brisebois, The Printing of Handbills in Quebec City, 1764-I800 (Anne Dondertman), p. 63; Manon Brunet, Vincent Dubost, Isabelle Lefebvre, et MarieÉlaine Savard, Henri Raymond Casgrain épistolier: Réseau et littérature au xix ${ }^{\mathrm{e}}$ siècle (Frédérick Durand), p. 65; Pauline Dubé, édit., Les frères insoumis ou "l'ombre d'un clocher», La Nouvelle-France sous Joseph-Antoine le Febvre de la Barre (1682-1685): Lettres, mémoires, instructions et ordonnances, François Dollier de Casson, Histoire du Montréal, et Louis-Antoine de Bougainville, Écrits sur le Canada: Mémoires, journal, lettres (François Melançon), p. 67; Shepard Krech, III, Native Canadian Anthropology and History: A Selected Bibliography (Sandra Bell), p. 72; George W. Crandell, Tennessee Williams: A Descriptive Bibliography (Drewey Wayne Gunn), p. 75; Maurice Annenberg, Type Foundries and Their Catalogs (Marie Korey), p. 77; Sue Allen and Charles Gullans, Decorated Cloth in America: Publishers' Bindings I 840-1910 (Bruce Whiteman), p. 78; O.M. Brack, Jr., ed., Writers, Books and Trade: An Eighteenth-Century English Miscellany for William B. Todd (Charlotte A. Stewart), p. 80; Barbara Kaye, Second Impression: Rural Life with a Rare Bookman (Helen R. Kahn), p. 82; David Pearson, Provenance Research in Book History (Gillian Fenwick), p. 83; John Carter, $A B C$ for Book Collectors and Frank J. Diehl, The Caxton Club 1895-1995: Celebrating a Century of the Book in Chicago (Richard Landon), p. 86. 


\section{Brief Notices / Notices abrégées}

Alan Horne and Guy Upjohn, Fine Printing: The Private Press in Canada, p. 9I; José C. Curto and/et Raymond R. Gervais, Bibliography of Canadian Master's Theses and Doctoral Dissertations on Africa I905-I993 / Bibliographie des mémoires de maîtrise et thèses de doctorat canadiens sur l'Afrique 1905-1993, p. 9I; Raymond Mougeon et Édouard Beniak, dir., Les origines du français québécois, p. 92; Barbara L. Craig and Peter D. James, A Guide to the Fonds d'Archives and Collections in the Holdings of the York University Archives, p. 93; Rosemary Foxton, 'Hear the Word of the Lord': A Critical and Bibliographical Study of Quaker Women's Writing, I650-1700, p. 94; Gifford Lewis, The Yeats Sisters and the Cuala, p. 95; Mark Samuels Lasner, A Selective Checklist of the Published Work of Aubrey Beardsley, p. 95; Gillian Fenwick, Women and the Dictionary of National Biography: A Guide to DN B Volumes I885-1985 and Missing Persons, p. 96; William Blissett and Alan Horne, David Jones, Artist @) Writer (I 895-1974): A Centennial Exhibition, p. 97; Charles Cutter and Micha Falk Oppenheim, Judaica Reference Sources: A Selective, Annotated Bibliographic Guide, p. 97; Bill Katz, ed., A History of Book Illustration: 29 Points of View, p. 98; John Dreyfus, Into Print: Selected Writings on Printing History, Typography and Book Production, p. 99. 